\title{
Gentamicin-induced preconditioning of proximal tubular LLC-PK1 cells stimulates nitric oxide production but not the synthesis of heat shock protein
}

\author{
E.A. Pessoa, M.B. Convento, R.G. Silva, A.S. Oliveira, F.T. Borges and N. Schor \\ Disciplina de Nefrologia, Departamento de Medicina, Escola Paulista de Medicina, Universidade Federal \\ de São Paulo, São Paulo, SP, Brasil
}

Correspondence to: N. Schor, Disciplina de Nefrologia, EPM, UNIFESP, Rua Botucatu, 740, 04023-900

São Paulo, SP, Brasil

Fax: +55-11-5573-9652. E-mail: nestor@nefro.epm.br

\begin{abstract}
Nephrotoxicity is the main side effect of antibiotics such as gentamicin. Preconditioning has been reported to protect against injuries as ischemia/reperfusion. The objective of the present study was to determine the effect of preconditioning with gentamicin on LLC-PK1 cells. Preconditioning was induced in LLC-PK1 cells by 24-h exposure to $2.0 \mathrm{mM}$ gentamicin (G/IU). After 4 or 15 days of preconditioning, cells were again exposed to gentamicin $(2.0 \mathrm{mM})$ and compared to untreated control or $\mathrm{G} /$ IU cells. Necrosis and apoptosis were assessed by acridine orange and HOESCHT 33346. Nitric oxide (NO) and endothelin-1 were assessed by the Griess method and available kit. Heat shock proteins were analyzed by Western blotting. After 15 days of preconditioning, LLC-PK1 cells exhibited a significant decrease in necrosis (23.5 \pm 4.3 to $6.5 \pm 0.3 \%)$ and apoptosis (23.5 \pm 4.3 to $6.5 \pm 2.1 \%)$ and an increase in cell proliferation compared to G/IU. NO $(0.177 \pm 0.05$ to $0.368 \pm 0.073 \mu \mathrm{g} / \mathrm{mg} \mathrm{protein})$ and endothelin-1 ( $1.88 \pm 0.47$ to $2.75 \pm 0.53 \mathrm{pg} / \mathrm{mL})$ production significantly increased after 15 days of preconditioning compared to G/IU. No difference in inducible HSP 70, constitutive HSC 70 or HSP 90 synthesis in tubular cells was observed after preconditioning with gentamicin. The present data suggest that preconditioning with gentamicin has protective effects on proximal tubular cells, that involved NO synthesis but not reduction of endothelin-1 or production of HSP 70, HSC 70, or HSP 90. We conclude that preconditioning could be a useful tool to prevent the nephrotoxicity induced by gentamicin.
\end{abstract}

Key words: Pre-conditioning; Gentamicin; Nitric oxide; LLC-PK1 cells; Acute kidney injury; Apoptosis

Research supported by CNPq, FINEP, Fundação Oswaldo Ramos (FOR), FAPESP, and CAPES.

Received July 21, 2008. Accepted April 16, 2009

\section{Introduction}

Exposure of an organ, tissue, or cells to a mild stress protects them against the effects of a subsequent equal or more severe stress $(1,2)$. This preconditioning phenomenon has been observed in various organs such as the brain (3), skeletal muscle (4), liver (5), intestine (6), lung (7), and kidney (8). It has also been reported in different kinds of injury such as ischemia (8) and heat shock (9). For example, the functional parameters of rat kidneys were im- proved by preconditioning with two successive cycles of ischemia/reperfusion (10). Pretreatment with vitamin D3 resulted in a protective effect against subsequent ischemia/reperfusion injury of the rat (11). Preconditioning can also induce crossover protection from another injury. For example, prior exposure of cultured neuronal cells to elevated temperature protects them against subsequent treatment with glutamate $(9,12)$.

The mechanisms involved in preconditioning are not fully understood, but may depend on the release of endog- 
enous protective mediators such as adenosine (13), prostacyclin (14), bradykinin (15), nitric oxide (NO) (9), opening of $\mathrm{K}_{\mathrm{ATP}}$ channels (16), endothelin 1 decrease (17), and heat shock protein (HSP) synthesis (18). The protective effect of the initial preconditioning stress may involve the ability of tissue to induce HSP synthesis $(19,20)$ and to increase NO production (21).

Gentamicin is an aminoglycoside antibiotic widely used for the treatment of Gram-negative infections and is a wellknown cause of renal failure, which occurs in $10-20 \%$ of patients receiving this drug (22). Gentamicin-induced nephrotoxicity is characterized by tubular necrosis mainly involving proximal tubules (23).

It has been shown that oxidative stress is involved in gentamicin-induced renal damage (24). There is also a marked decrease in glomerular filtration rate, ultrafiltration coefficient and glomerular plasma flow (25). Gentamicininduced nephrotoxicity has been only prevented in clinical practice by the use of antioxidants such as n-acetylcysteine (26). Specific and effective strategies are necessary to treat or prevent nephrotoxicity induced by gentamicin.

The objective of the present study was to determine the effect of preconditioning with gentamicin on proximal tubular epithelial cells (LLC-PK1) by measuring necrosis, apoptosis and proliferation rates, endothelin-1, NO synthesis, and HSP expression.

\section{Material and Methods}

\section{Cell culture}

LLC-PK1, derived from the renal epithelial cells of Hampshire pigs and presenting the proximal tubule phenotype, were purchased from the American Type Culture Collection and grown in Dulbecco's modified Eagle's medium (DMEM, Sigma, USA) supplemented with 5\% fetal bovine serum (FBS, Gibco, USA), $24 \mathrm{mM} \mathrm{NaHCO}_{3}, 10 \mathrm{mM}$ N'-2-hydroxyethylpiperazine-N'-2-ethanesulfonic acid, and $10,000 \mathrm{U} / \mathrm{L}$ penicillin/streptomycin. Cells were grown to semiconfluence at $37^{\circ} \mathrm{C}$ in a humidified atmosphere containing $5 \%$ carbon dioxide, and then, $0.5 \%(\mathrm{w} / \mathrm{v})$ trypsin (Cultilab, Brazil) was used to detach the cells from the plastic flasks. The cells were subsequently centrifuged, resuspended in DMEM, and subcultured in $25-\mathrm{cm}^{2}$ plastic culture flasks or 6-well plates for the experimental procedures.

\section{Experimental groups}

After semiconfluence was reached, the medium was replaced with FBS-free DMEM and the $1 \times 10^{6}$ cells were assigned to the following treatment groups: control (CTL), cells exposed to FBS-free DMEM for $24 \mathrm{~h}$; G/IU, cells treated with $2 \mathrm{mM}$ gentamicin for $24 \mathrm{~h}$; G/ID-4d, cells previously exposed to $2.0 \mathrm{mM}$ gentamicin for $24 \mathrm{~h}$ and treated again with $2.0 \mathrm{mM}$ gentamicin for $24 \mathrm{~h}, 4$ days after the first insult; G/ID-15d, cells previously exposed to gentamicin for $24 \mathrm{~h}$ and treated again with gentamicin for $24 \mathrm{~h}$ 15 days after the first insult. At least 6 experimental situations in each group were analyzed.

\section{Cell viability}

Cell viability was determined by the exclusion of the fluorescent dyes acridine orange and ethidium bromide (Sigma) (27). Cells were trypsinized and $10 \mu \mathrm{L}$ of the cell suspensions was incubated with $0.3 \mu \mathrm{L}$ acridine orange/ ethidium bromide solution $(100 \mu \mathrm{g} / \mathrm{mL})$. Ethidium bromide is cell permeable and binds to either double-stranded DNA emitting a green fluorescence (excitation $502 \mathrm{~nm}$ and emission $525 \mathrm{~nm}$ ), or to the single-stranded RNA emitting a reddish-orange fluorescence (excitation $460 \mathrm{~nm}$ and emission $650 \mathrm{~nm}$ ). In contrast, acridine orange binds only to double-stranded DNA and emits a red fluorescence (excitation $510 \mathrm{~nm}$ and emission $595 \mathrm{~nm}$ ); however, the cell is not permeable to the dye when the plasma membrane is intact, and therefore only necrotic cells will take up this dye (with the red fluorescence quashing the green/ orange of acridine orange). Cell suspensions were observed under a fluorescent microscope at 40X magnification, and 200 cells per culture flasks were counted. Cells emitting green fluorescence were considered viable, and those emitting red fluorescence were considered nonviable (necrotic). Viable cells are reported as a percentage of the total cells counted.

\section{Apoptosis}

Apoptotic cells were determined using the HOE 33342 [Bisbenzimide HOE 33342 (2'-[4-ethoxyphenyl]-5-[4-methyl-1-piperazinyl]-2,5'-bi-1H-benzimidazole) trihydrochloride] dye. LLC-PK1 suspensions were centrifuged, resuspended in PBS and incubated with $10 \mu \mathrm{L}$ HOE 33342 (1.0 mM) solution for 5-15 min for chromatin staining (28).

Cells were observed under the light microscope. Blue cells were considered to be non-apoptotic, and cells with condensed chromatin were considered to be apoptotic. At least 100 cells per culture flask were counted, and the results are reported as percentage of necrotic or apoptotic cells.

\section{Proliferation}

Cell proliferation was determined by cell counting. LLCPK1 control cells $\left(1 \times 10^{4}\right.$ cell) were seeded onto 24-well plates and treated with DMEM + 0.5\% FBS. LLC-PK1 cells previously exposed to gentamicin for 15 days (G/ID-15d) 
or cells without any treatment (G/IU) were seeded onto 24well plates and treated with DMEM $+0.5 \%$ FBS and 2.0 $\mathrm{mM}$ gentamicin. Cells were counted in a Neubauer chamber with Trypan blue at 12-h intervals for 6 days and the results are reported as mean \pm SE number of viable cells.

\section{Endothelin-1 synthesis}

The concentration of endothelin-1 in cell suspensions was measured with a commercial ELISA kit (IBL Co., Japan).

The concentrations of endothelin- 1 were assessed in culture medium of LLC-PK1 cells preconditioned with gentamicin (G/ID) or not (CTL and $G / I U)$. All assays were performed in triplicate according to manufacturer protocols. The absorbance $(450 \mathrm{~nm})$ of each sample was read by the Ultra Microplate Reader EL808 (Bio-Tek Instruments, USA) and is reported as $\mathrm{pg} / \mathrm{mL}$. The sensitivity of the method was $0.78 \sim 100 \mathrm{pg} / \mathrm{mL}$. The inter-assay variation was $4.96 \pm 0.40, \mathrm{CV}=8.1 \%$, and the intra-assay variation was $4.76 \pm 0.40, \mathrm{CV}=8.5 \%$

\section{Nitric oxide determination}

$\mathrm{NO}$ in the cell culture media was determined by Griess (29). Briefly, a solution of $1 \%$ sulfanilamide in $5 \% \mathrm{H}_{3} \mathrm{PO}_{4}$ containing $0.1 \%$ naphthylethylenediamine (Sigma) was added to aliquots of media and absorbance at $546 \mathrm{~nm}$ was measured using a GENESYS 2 spectrophotometer (Spectronic Instruments, Inc., USA). Nitrite, one of the stable metabolites of $\mathrm{NO}$, was then estimated by comparison with a standard curve constructed with $\mathrm{NaNO}_{2}$. The protein content of the culture media was assessed by the method of Lowry et al. (30) and the absorbance compared to an albumin standard curve. NO quantification was reported in $\mu \mathrm{g} / \mathrm{mg}$ of protein in each experimental situation.

\section{Western blotting}

Cells were lysed with $600 \mu \mathrm{L}$ lysis buffer $(50 \mathrm{mM}$ Tris, $\mathrm{pH}$ 8.0, $150 \mathrm{mM} \mathrm{NaCl}, 1 \%$ Nonidet P-40, 0.5\% sodium deoxycholate, $0.1 \%$ SDS, $2.5 \mathrm{mM}$ EDTA, $1 \mathrm{mM} \mathrm{PMSF}$, and $44 \mathrm{mM}$ o-phenanthrolene) per plate $(100 / 20 \mathrm{~mm})$. The lysates were centrifuged at $12,000 \mathrm{~g}$ for $5 \mathrm{~min}$ at $4^{\circ} \mathrm{C}$ and the supernatants were stored at $-80^{\circ} \mathrm{C}$. Protein concentration was determined with the reagents from BioRad (USA) by the Bradford method, using a calibration curve containing bovine serum albumin. Lysate containing $30 \mu \mathrm{g}$ protein was separated by $7.5-10 \%$ sodium dodecyl sulfate polyacrylamide gel electrophoresis and electrophoretically transferred to nitrocellulose membranes using a TransBlot SD Semi-Dry Electrophoretic Transfer Cell (BioRad).

Nonspecific binding sites were blocked with $5 \%$ non-fat dried milk (v/v) in TBS buffer containing $10 \mathrm{mM}$ Tris- $\mathrm{HCl}$,
$\mathrm{pH} 7.5$, and $200 \mathrm{mM} \mathrm{NaCl}$. Immunoblots were incubated overnight at $4^{\circ} \mathrm{C}$ with the following primary antibodies: 1:1000 HSP 70, 1:1000 HSP 90, 1:1000 constitutive HSP (HSC) 70 (Stressgen, Assay Designs, USA), and 1:2000 inducible NO synthase (iNOS, Santa Cruz, USA). After washing three times with TBS-T (Tris- $\mathrm{HCl}, \mathrm{pH} 7.5,200 \mathrm{mM}$ $\mathrm{NaCl}, 0.05 \%$ Tween-20), membranes were incubated for 1 $\mathrm{h}$ at $4^{\circ} \mathrm{C}$ in alkaline phosphatase-conjugated secondary antibodies (1:1000; Stressgen, Assay Designs) and then washed three times with TBS-T. Immunoreactive protein bands were visualized using the NBT/BCIP detecting reagents (Molecular Probes, Invitrogen, USA). Nitrocellulose membranes were scanned digitally and analyzed using an Imaging Densitometer (Model GS670, USA) and the Quantity One-GS710 software (USA).

\section{Statistical analysis}

Data are reported as means \pm SEM. The experimental and control groups were compared by one-way analysis of variance (ANOVA) followed by the Dunn or Tukey test for multiple comparisons, with the level of significance set at $5 \%(P<0.05)$.

\section{Results}

Figure 1A shows the necrotic death of LLC-PK1 cells preconditioned or not with gentamicin. Necrotic cell death after treatment with gentamicin increased significantly compared to control (G/IU: $23.5 \pm 4.3$ vs CTL: $11.8 \pm 4.5 \%$; $\mathrm{P}<$ 0.05 , respectively). After 4 days of preconditioning, there was no difference in the necrosis rate induced by gentamicin (G/ID-4d: $23.9 \pm 8.3 \%$ ) compared to G/IU, but after 15 days of preconditioning, the necrosis rate induced by gentamicin decreased significantly (G/ID-15d: $6.56 \pm 0.3 \%$ ) compared to $\mathrm{G} / \mathrm{IU}$.

Figure 1B shows the apoptotic rate of LLC-PK1 cells preconditioned with gentamicin. There was a significant increase in apoptotic cells after treatment with gentamicin compared to control (G/IU: $26.5 \pm 2.8$ vs CTL: $3.2 \pm 1.2 \%$ ). After 4 days (G/ID-4d) of preconditioning, there was a significant decrease in the apoptotic rate from $26.5 \pm 2.8$ to $4.6 \pm 1.5 \%$, which persisted after 15 days of preconditioning (G/ID-15d: $6.5 \pm 2.1 \%)$.

Figure 1C shows the proliferation pattern of LLC-PK1 cells preconditioned with gentamicin in the same experimental situations. There was a decrease in cell proliferation after treatment with gentamicin (G/IU) compared to control. After preconditioning with gentamicin for 15 days (G/ID-15d), proliferation was increased compared to control even in the presence of gentamicin.

In an attempt to identify mechanisms of protection 

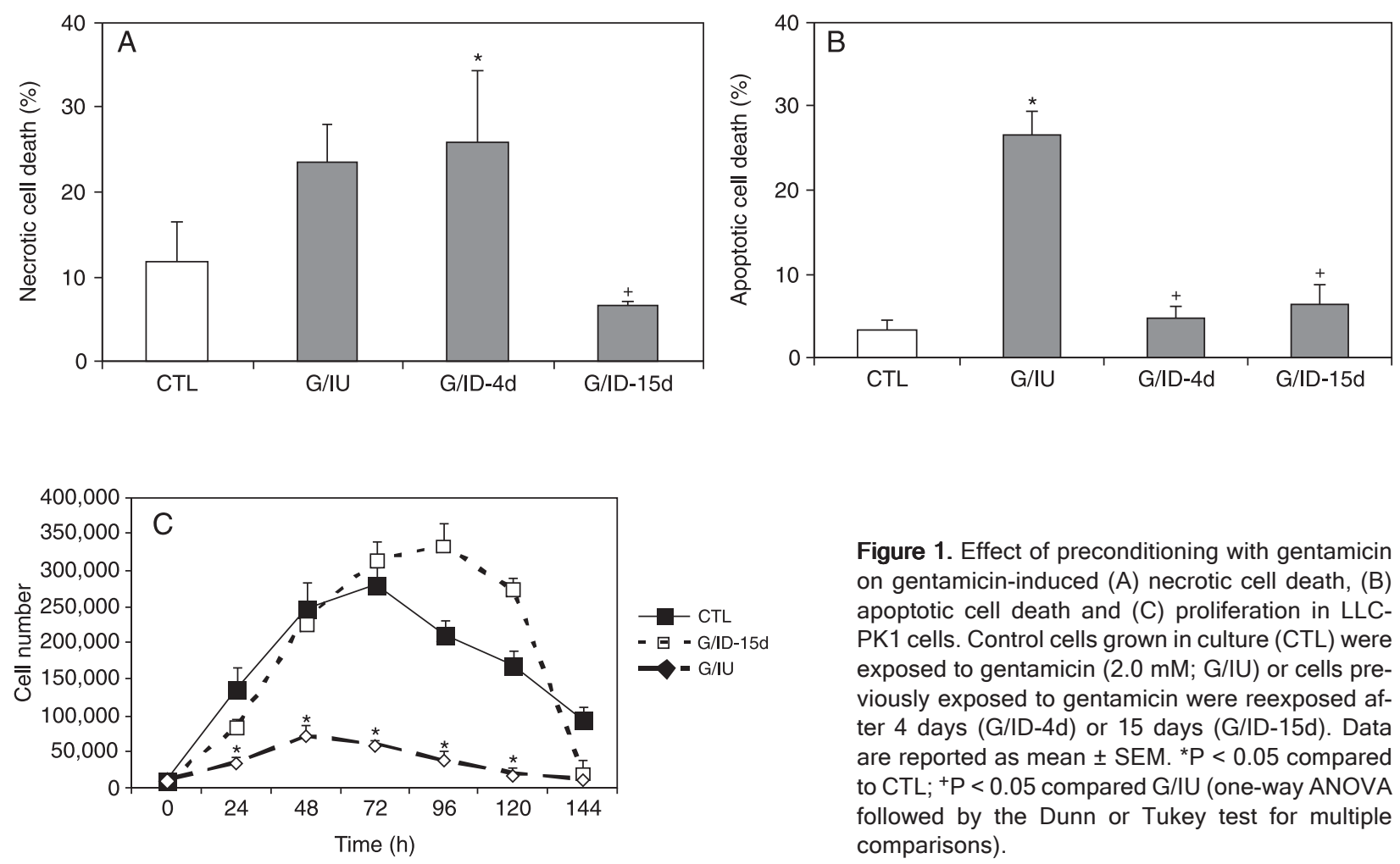

Figure 1. Effect of preconditioning with gentamicin on gentamicin-induced (A) necrotic cell death, $(B)$ apoptotic cell death and (C) proliferation in LLCPK1 cells. Control cells grown in culture (CTL) were exposed to gentamicin $(2.0 \mathrm{mM}$; G/IU) or cells previously exposed to gentamicin were reexposed after 4 days (G/ID-4d) or 15 days (G/ID-15d). Data are reported as mean \pm SEM. ${ }^{*} P<0.05$ compared to $\mathrm{CTL} ;{ }^{+} \mathrm{P}<0.05$ compared G/IU (one-way ANOVA followed by the Dunn or Tukey test for multiple comparisons).

induced by preconditioning with gentamicin in LLC-PK1 cells, we determined NO production in the culture medium of LLC-PK1 cells preconditioned with gentamicin (Figure $2 \mathrm{~A})$. There was no difference in NO production between tubular cells exposed to gentamicin and control (G/IU: $0.172 \pm 0.014$ vs CTL: $0.177 \pm 0.05 \mu \mathrm{M} / \mathrm{mg}$ protein) . Nevertheless, in tubular cells preconditioned with gentamicin there was a significant increase in NO production after 15 days (G/ID-15d: $0.368 \pm 0.073 \mu \mathrm{M} / \mathrm{mg}$ protein).

In Figure 2B, we report the viability of LLC-PK1 cells preconditioned with gentamicin for 15 days in the presence or not of $5 \mathrm{mM}$ L-NAME. There was a significant increase in apoptotic and necrotic cell death after treatment with gentamicin. After 15 days of preconditioning, the necrotic and apoptotic rate returned to control levels. However, in the presence of L-NAME, there was a significant increase in necrosis (G/ID-15d: $6.6 \pm 1.1$ vs G/ID-15d + L-NAME: $81.6 \pm$ $1.9 \%$ ) and apoptosis (G/ID-15d: $12.3 \pm 1.6$ vs G/ID-15d + LNAME: $85.3 \pm 1.7 \%$ ) of cells preconditioned for 15 days. The treatment of LLC-PK1 cells with gentamicin induced the expression of iNOS, which persisted for at least 15 days after preconditioning with gentamicin (Figure $2 \mathrm{C}$ ).

Figure 2D shows endothelin-1 synthesis in LLC-PK1 cells preconditioned with gentamicin. There was a signifi- cant increase in endothelin-1 production when tubular cells were exposed to gentamicin compared to control (G/ IU: $1.88 \pm 0.47 ;$ CTL: $0.40 \pm 0.22 \mathrm{pg} / \mathrm{mL}$ ), which persisted after 15 days of preconditioning (G/ID-15d: $2.76 \pm 0.52 \mathrm{pg} /$ $\mathrm{mL})$.

Under the conditions employed in the present study, preconditioning of LLC-PK1 cells with gentamicin did not induce HSP 70 (G-ID/15d: $2.8 \pm 0.9$; G-IU: $2.8 \pm 0.8$; CTL: $2.9 \pm 0.6$ pixels ratio between HSP 70/ $\beta$-actin), HSC 70 (GID/15d: $1.9 \pm 0.4$; G-IU: $2.1 \pm 0.3$; CTL: $2.4 \pm 0.5$ pixels ratio between HSC 70/ $\beta$-actin), or HSP 90 (G-ID/15d: $1.1 \pm 0.3$; G-IU: $1.0 \pm 0.3$; CTL: $0.9 \pm 0.2$ pixels ratio between HSP $90 / \beta$-actin) production compared to $\mathrm{G} / \mathrm{IU}$ or control condition.

\section{Discussion}

The protective mechanisms induced by preconditioning with gentamicin in the kidney are unknown. The aim of the present study was to evaluate the consequences of preconditioning with gentamicin in proximal tubular cells. The nephrotoxicity induced by gentamicin is characterized by tubular cell damage (31) and a reduction of renal blood flow and glomerular filtration rate (25). 

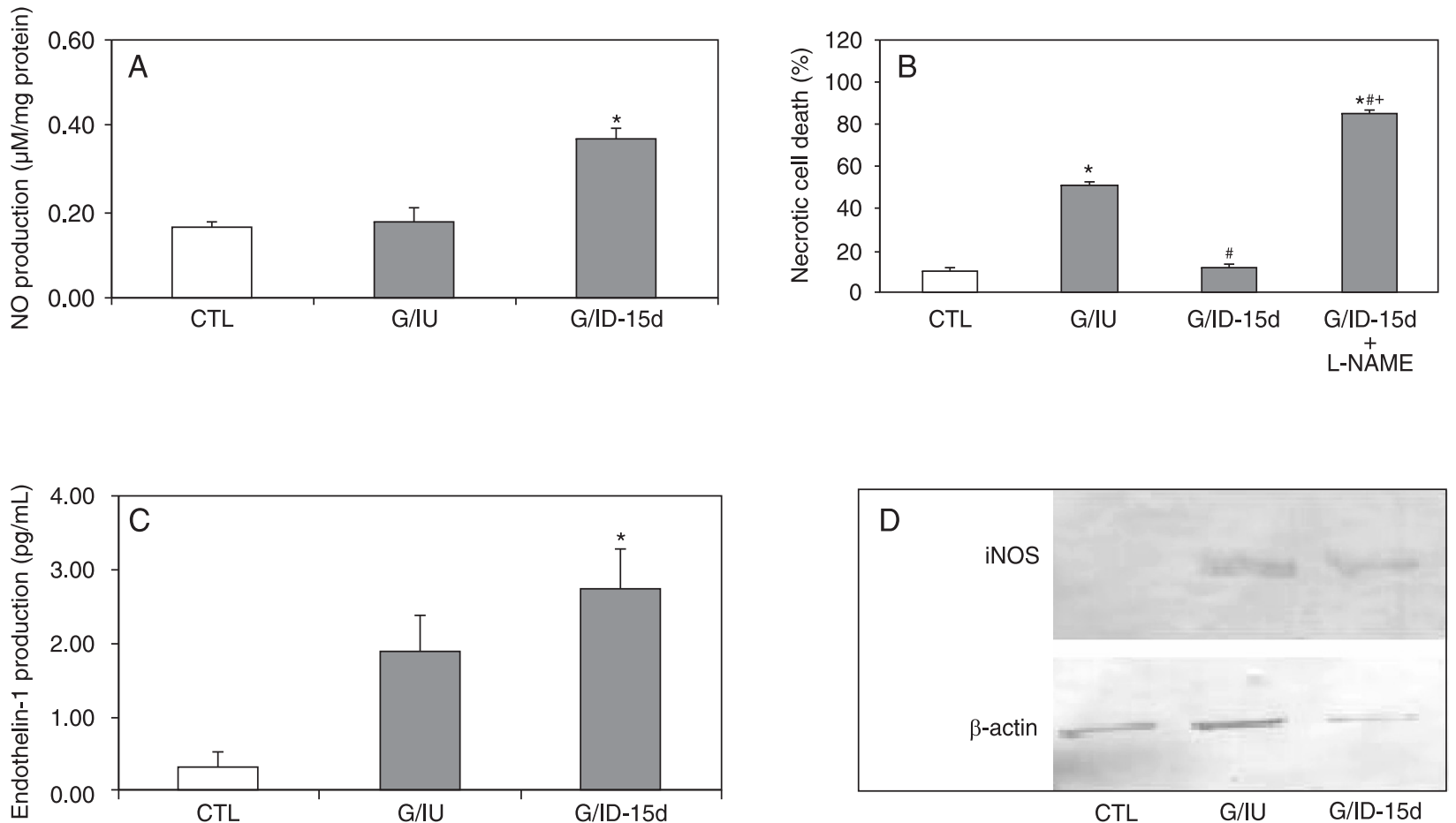

Figure 2. Effect of preconditioning with gentamicin on (A) nitric oxide production, (B) necrotic cell death, (C) endothelin-1 production, and (D) iNOS expression by Western blotting. Control cells were grown in culture (CTL), exposed to gentamicin (2.0 mM; G/IU) or reexposed after 15 days (G/ID-15d) to gentamicin with or without L-NAME (5 mM) (G/ID-15d + L-NAME). *P<0.05 compared to CTL; ${ }^{\#} \mathrm{P}<0.05$ compared to $\mathrm{G} / \mathrm{IU}$; ${ }^{+} \mathrm{P}<0.05$ compared to G/ID-15d (one-way ANOVA followed by the Dunn or Tukey test for multiple comparisons).

A significant decrease in gentamicin-induced apoptosis was observed after 4 days of preconditioning in tubular cells, but the decrease in necrosis only occurred after 15 days. Preconditioning with gentamicin for 15 days increased the proliferation of LLC-PK1 cells even in the presence of the drug. In rat mesangial cells, incubation with gentamicin induced apoptosis and proliferation (22).

The involvement of renal NO production in preconditioning induced by ischemia/reperfusion has been previously proposed (32). Also, an increase in glomerular NO production has been reported in rats with gentamicininduced renal failure (33).

The present study shows that NO production is involved in preconditioning induced by gentamicin in LLCPK1 cells because preconditioning with gentamicin for 15 days resulted in a significant increase in NO production and in iNOS expression in proximal tubular cells compared to control. To our knowledge, this is the first time one study shows that inhibition of constitutive and induced NO synthase with L-NAME significantly increased necrotic and apoptotic cell death in preconditioned LLC-PK1 cells, showing that protection of preconditioning with gentamicin is dependent on NO production.

Endothelin-1 stimulates hypertrophy, proliferation, and extracellular matrix accumulation in the kidney, primarily via endothelin type $A(E T A)$ receptor stimulation. Selective ETA receptor antagonists as well as combined ETA/ETB receptor antagonists prevent the development of hypertension, renal vasoconstriction, proteinuria, increased renal matrix protein expression, and renal structural injury in diabetic rats (34). A decrease in endothelin-1 overproduction was observed in ischemia/reperfusion preconditioning in rats $(35,36)$. However, a decrease of endothelin- 1 was not observed in the preconditioning induced by gentamicin in proximal tubular cells in the present protocol. We did not observe inhibition of gentamicin-induced endothelin-1 overproduction after preconditioning for 15 days. It is possible that the increase in endothelin-1 in LLC-PK1 cells after preconditioning with gentamicin is related to the proliferation observed in our experimental model.

Some studies have reported the participation of HSP in several preconditioning models. The increase in HSP 70 is directly proportional to the degree of protection induced by ischemic or heat preconditioning in neuronal cells (37). In 
contrast, overexpression of HSP 70 in the kidney after ischemic or thermal preconditioning does not correlate with protection from hypoxic injury (38). Our results agree with these findings since we did not observe any increase in inducible HSP 70, constitutive HSC 70 or HSP 90 in the present experimental situation.

Our results showed that NO is involved in preconditioning induced by gentamicin of kidney tubular cells. Treatment with NO donors could be a useful tool to treat or prevent this nephrotoxicity.

\section{References}

1. Plesset J, Palm C, McLaughlin CS. Induction of heat shock proteins and thermotolerance by ethanol in Saccharomyces cerevisiae. Biochem Biophys Res Commun 1982; 108: 1340-1345.

2. Yellon DM, Latchman DS. Stress proteins and myocardial protection. J Mol Cell Cardiol 1992; 24: 113-124.

3. Perez-Pinzon MA, Xu GP, Dietrich WD, Rosenthal M, Sick TJ. Rapid preconditioning protects rats against ischemic neuronal damage after 3 but not 7 days of reperfusion following global cerebral ischemia. J Cereb Blood Flow Metab 1997; 17: 175-182.

4. Lee HT, Lineaweaver WC. Protection against ischemicreperfusion injury of skeletal muscle: role of ischemic preconditioning and adenosine pretreatment. J Reconstr Microsurg 1996; 12: 383-388.

5. Lloris-Carsi JM, Cejalvo D, Toledo-Pereyra LH, Calvo MA, Suzuki S. Preconditioning: effect upon lesion modulation in warm liver ischemia. Transplant Proc 1993; 25: 3303-3304.

6. Hotter G, Closa D, Prados M, Fernandez-Cruz L, Prats N, Gelpi $\mathrm{E}$, et al. Intestinal preconditioning is mediated by a transient increase in nitric oxide. Biochem Biophys Res Commun 1996; 222: 27-32.

7. Neely CF, Keith IM. A1 adenosine receptor antagonists block ischemia-reperfusion injury of the lung. Am J Physiol 1995; 268: L1036-L1046.

8. Cochrane J, Williams BT, Banerjee A, Harken AH, Burke TJ, Cairns CB, et al. Ischemic preconditioning attenuates functional, metabolic, and morphologic injury from ischemic acute renal failure in the rat. Ren Fail 1999; 21: 135-145.

9. Rordorf G, Koroshetz WJ, Bonventre JV. Heat shock protects cultured neurons from glutamate toxicity. Neuron 1991; 7: 1043-1051.

10. Kim YO, Li C, Sun BK, Kim JS, Lim SW, Choi BS, et al. Preconditioning with 1,25-dihydroxyvitamin D3 protects against subsequent ischemia-reperfusion injury in the rat kidney. Nephron Exp Nephrol 2005; 100: e85-e94.

11. Mahfoudh-Boussaid A, Badet L, Zaouali A, SaidaneMosbahi D, Miled A, Ben AH. [Effect of ischaemic preconditioning and vitamin $\mathrm{C}$ on functional recovery of ischaemic kidneys]. Prog Urol 2007; 17: 836-840.

12. Lowenstein $\mathrm{DH}$, Chan $\mathrm{PH}$, Miles MF. The stress protein response in cultured neurons: characterization and evidence for a protective role in excitotoxicity. Neuron 1991; 7: 10531060.

13. Sugino $H$, Shimada H, Tsuchimoto K. Role of adenosine in renal protection induced by a brief episode of ischemic preconditioning in rats. Jpn J Pharmacol 2001; 87: 134-142.

14. Shinmura K, Nagai M, Tamaki K, Tani M, Bolli R. COX-2- derived prostacyclin mediates opioid-induced late phase of preconditioning in isolated rat hearts. Am J Physiol Heart Circ Physiol 2002; 283: H2534-H2543.

15. Kositprapa C, Ockaili RA, Kukreja RC. Bradykinin B2 receptor is involved in the late phase of preconditioning in rabbit heart. J Mol Cell Cardiol 2001; 33: 1355-1362.

16. Haruna T, Horie M, Kouchi I, Nawada R, Tsuchiya K, Akao $\mathrm{M}$, et al. Coordinate interaction between ATP-sensitive $\mathrm{K}^{+}$ channel and $\mathrm{Na}^{+}, \mathrm{K}^{+}$-ATPase modulates ischemic preconditioning. Circulation 1998; 98: 2905-2910.

17. Saito T, Fushimi E, Tamura T, Fujiwara Y, Miura H, Watanabe $\mathrm{H}$, et al. L-nitro-arginine inhibits increase in endothelin binding sites induced by ischemia and reperfusion. $\mathrm{J} \mathrm{Mol}$ Cell Cardiol 2002; 34: 1041-1047.

18. Heads RJ, Latchman DS, Yellon DM. Stable high level expression of a transfected human HSP70 gene protects a heart-derived muscle cell line against thermal stress. $J \mathrm{Mol}$ Cell Cardiol 1994; 26: 695-699.

19. Lindquist S. Translational efficiency of heat-induced messages in Drosophila melanogaster cells. J Mol Biol 1980; 137: $151-158$

20. Lindquist S, Craig EA. The heat-shock proteins. Annu Rev Genet 1988; 22: 631-677.

21. Chander V, Chopra K. Role of nitric oxide in resveratrolinduced renal protective effects of ischemic preconditioning. J Vasc Surg 2005; 42: 1198-1205.

22. Ali $\mathrm{BH}$. Gentamicin nephrotoxicity in humans and animals: some recent research. Gen Pharmacol 1995; 26: 14771487.

23. Bennett WM. Comparison of cyclosporine nephrotoxicity with aminoglycoside nephrotoxicity. Clin Nephrol 1986; 25 (Suppl 1): S126-S129.

24. Cuzzocrea S, Mazzon E, Dugo L, Serraino I, Di Paola R, Britti $D$, et al. A role for superoxide in gentamicin-mediated nephropathy in rats. Eur J Pharmacol 2002; 450: 67-76.

25. Schor N, Ichikawa I, Rennke HG, Troy JL, Brenner BM. Pathophysiology of altered glomerular function in aminoglycoside-treated rats. Kidney Int 1981; 19: 288-296.

26. Levin A, Pate GE, Shalansky S, Al-Shamari A, Webb JG, Buller $\mathrm{CE}$, et al. $\mathrm{N}$-acetylcysteine reduces urinary albumin excretion following contrast administration: evidence of biological effect. Nephrol Dial Transplant 2007; 22: 2520-2524.

27. Coico R. In vitro assays for mouse $B$ and $T$ cell function. Related isolation procedures and functional assays. In: Coligan JE, Kruisbeek AM, Margulies DH, Shevach EM, Strober W (Editors), Current protocols in immunology. Vol. 3.17. New York: John Wiley \& Sons, Inc.; 1995. p 1-33.

28. Filatov MV, Varfolomeeva EY. Active dissociation of 
Hoechst 33342 from DNA in living mammalian cells. Mutat Res 1995; 327: 209-215.

29. Green LC, Wagner DA, Glogowski J, Skipper PL, Wishnok JS, Tannenbaum SR. Analysis of nitrate, nitrite, and [15N]nitrate in biological fluids. Anal Biochem 1982; 126: 131-138.

30. Lowry $\mathrm{OH}$, Rosebrough NJ, Farr AL, Randall RJ. Protein measurement with the Folin phenol reagent. $J$ Biol Chem 1951; 193: 265-275.

31. Kacew S, Bergeron MG. Pathogenic factors in aminoglycoside-induced nephrotoxicity. Toxicol Lett 1990; 51: 241 259.

32. Murry CE, Jennings RB, Reimer KA. Preconditioning with ischemia: a delay of lethal cell injury in ischemic myocardium. Circulation 1986; 74: 1124-1136.

33. Rivas-Cabanero L, Montero A, Lopez-Novoa JM. Increased glomerular nitric oxide synthesis in gentamicin-induced renal failure. Eur J Pharmacol 1994; 270: 119-121.

34. Sasser JM, Sullivan JC, Hobbs JL, Yamamoto T, Pollock
DM, Carmines PK, et al. Endothelin A receptor blockade reduces diabetic renal injury via an anti-inflammatory mechanism. J Am Soc Nephrol 2007; 18: 143-154.

35. Yamashita J, Ogata M, Itoh M, Yamasowa $\mathrm{H}$, Shimeda $\mathrm{Y}$, Takaoka M, et al. Role of nitric oxide in the renal protective effects of ischemic preconditioning. $J$ Cardiovasc Pharmacol 2003; 42: 419-427.

36. Liu X, Chen $\mathrm{H}$, Zhan B, Xing B, Zhou J, Zhu H, et al. Attenuation of reperfusion injury by renal ischemic postconditioning: the role of NO. Biochem Biophys Res Commun 2007; 359: 628-634.

37. Amin V, Cumming DV, Coffin RS, Latchman DS. The degree of protection provided to neuronal cells by a preconditioning stress correlates with the amount of heat shock protein 70 it induces and not with the similarity of the subsequent stress. Neurosci Lett 1995; 200: 85-88.

38. Turman MA, Rosenfeld SL. Heat shock protein 70 overexpression protects LLC-PK1 tubular cells from heat shock but not hypoxia. Kidney Int 1999; 55: 189-197. 